\title{
Distribution of Natural Uranium in Subsurface sediment and Groundwater Resources in Southwest Parts of Punjab State, India.
}

\author{
DEBABRATA DAS*, RITU BALA
}

Department of Geology, Panjab University, Chandigarh, 160014, India (*correspondence: debabratadas@pu.ac.in)

Keeping in view the toxicity of uranium and to reduce exposure to uranium and avoid high doses, it is essential to examine on routine bases the concentration of natural radionuclide uranium (U) in surface and groundwater resources [1]. Uranium contamination of groundwater is a rising issue in northern India [2]. In this approach, the concentrations of $U$ (total $U$ ) were measure in subsurface alluvium soil and groundwater resources of Southwest Parts of Punjab State, Northern India. The objectives of this study were to (1) show the processes leading to uranium distribution in the subsurface sediment and groundwater to the relative influence of reduction and oxidation changes and role of agriculture on the dispersion of particulate Uranium, and (2) to identify primary/secondary $U$ minerals and the associated alteration products. Analysis of hydrogeochemical and geochemical parameters revealed a strong correlation between $\mathrm{U}$ and bicarbonate and strontium in groundwater and moderately strong relation between $\mathrm{U}$ and $\mathrm{Te}, \mathrm{Au}, \mathrm{Ni}, \mathrm{Pb}$ in subsurface sediment. Relatively higher concentrations of $\mathrm{Au}$, $\mathrm{V}, \mathrm{Ni}, \mathrm{V}, \mathrm{Th}$ and REE (Nd, Ce, Pr, Eu) have been associated with uraniferous mineral in shallow subsoil. The groundwater uranium content in the study area varied from $35 \mu \mathrm{g} / \mathrm{L}$ to 260 $\mu \mathrm{g} / \mathrm{L}$ in different level of aquifers. $\mathrm{Th} / \mathrm{U}$ ratio was calculated to know the sedimentary processes in the region and its reveal strong oxidizing environment in subsoil with $\mathrm{Th} / \mathrm{U}$ ratio range from 3.84- 5.89. A rare secondary uranium mineral Cliffordite (very rare tellurium mineral) found with low concentration in the clay layer associated with lead, barite, quartz and limonite Uranium is solubilised from the sediment sample in both carbonate and bicarbonate leaching systems. Secondary uranium species are eventually adsorbs interstitial iron oxide forms as reducing conditions were re-established due to water-rock interactions. Carnotite and Autunite were the most abundant secondary Uranium minerals deposit, whereas Kaolinite and Illite represent low temperature alteration products of the host of alluvium sediments

[1] Amir Waseem et al. (2015), Journal of Critical Reviews in Environmental Science and TechnologyInt. 45(22), 2391423. [2] Rachel M. Coyte et al. (2018), Environ. Sci. Technol. letter, 5(9), 593-594. 